\title{
Nilai Estetis Penampilan Busana Pengantin Gaya Solo Basahan di Surakarta Hadiningrat
}

\author{
Addiina Purnawangsih ${ }^{1}$, Margana ${ }^{2}$, Edi Try Sulistyo ${ }^{3}$ \\ Pendidikan Seni, Pascasarjana, Universitas Sebelas Maret, \\ J1. Ir. Sutami No. 36A Kentingan, Surakarta, 57126, Indonesia \\ laddiinapurnawangsih@gmail.com
}

Busana pengantin gaya Solo Basahan merupakan busana adat di Surakarta, Jawa Tengah. Upacara panggih menjadi puncak rangkaian prosesi pernikahan yang dalam pelaksanaannya menggunakan busana pengantin gaya Solo Basahan. Penelitian ini bertujuan untuk mendeskripsikan dan menjelaskan nilai estetis yang terkandung dalam penampilan busana pengantin gaya Solo Basahan di Surakarta Hadiningrat. Penelitian ini merupakan penelitian kualitatif dengan menggunakan model analisis interaktif. Sumber data dalam penelitian ini adalah dokumentasi prosesi pernikahan dan catatan lapangan. Teknik pengumpulan data dilakukan dengan mencatat, merekam, dan mewawancarai. Analisis data dengan mendeskripsikan dan menjelaskan setiap rangkaian prosesi pernikahan yang menggunakan busana pengantin Solo Basahan. Hasil penelitian ini adalah nilai-nilai yang terkandung dalam penampilan busana pengantin Gaya Solo Basahan di Surakarta Hadiningrat berupa wujud pertunjukkan seni oleh pengantin yang menjadi raja dan ratu sehari yang di dalamnya terkandung nilai-nilai meliputi kasihsayang, rasa bakti, tanggung jawab, kesetiaan, kebahagiaan, keserasian, semangat, kemesraan, kejujuran, keharmonisan, dan kesopanan. Nilai-nilai tersebut menjadi representasi nilai estetis busana Solo Basahan sebagai bentuk pertunjukkan seni yang terdapat dalam upacara panggih yang meliputi Balangan Gantal, Wiji Dadi, Sindur Binayang, Bobot Timbang, Tanem, Kacar-kucur, Dhahar Kembul, Mertui, dan Sungkem.

Kata kunci : nilai, estetis, Solo Basahan

\section{Aesthetic Value of Solo Basahan Style Bridal Clothing in Surakarta Hadiningrat}

Solo Basahan style wedding dress is a traditional dress in Surakarta, Central Java. The panggih ceremony became the top of a series of wedding processions which in its implementation used the Solo Basahan bridal costume. This study aims to describe and explain the aesthetic value contained in the appearance of Solo Basahan style bridal clothing in Surakarta Hadiningrat. This research is a qualitative study using an interactive analysis model. The data source in this study is the documentation of the marriage procession and field notes. Data collection techniques carried out by writing, recording and interview. Data analysis by describing and describing each series of wedding processions using the Solo Basahan bridal costume. The results of this study are the values contained in the appearance of Solo Basahan bridal fashion in Surakarta Hadiningrat in the form of art performance by brides who become king and queen a day in which there are values including love, responsibility, loyalty, happiness, harmony, passion, intimacy, honesty, and politeness. These values represent the aesthetic value of Solo Basahan fashion as a form of art performance contained in the panggih ceremony which includes Balangan Gantal, Wiji Dadi, Sindur Binayang, Bobot Timbang, Kacar-kucur, Dhahar Kembul, Mertui, dan Sungkem.

Keywords : value, asthetic, Solo Basahan

Proses Review : 1 - 20 Mei 2020, Dinyatakan Lolos: 29 Mei 2020 


\section{PENDAHULUAN}

Pernikahan merupakan salah satu peristiwa penting yang sakral dan suci dalam sejarah kehidupan manusia. Setiap daerah mempunyai keagungan, kekhasan, keunikan dan keindahannya sendiri yang mengandung nilai budaya luhur warisan nenek moyang. Dilihat dari sisi etnis dan budaya setiap daerah menunjukkan karakteristik keberagaman budaya adat bangsa Indonesia, selain itu karakteristik tersebut mengandung nilai luhur yang memiliki sumber daya kearifan lokal budaya. Setiap etnis memiliki kearifan lokal sendiri, termasuk tata rias dan busana pernikahan. Adat istiadatnyapun mengandung nilai luhur lokal budaya Jawa yang merupakan tradisi yang bersumber dari Keraton.

Serangkaian upacara pernikahan mengandung nilai-nilai luhur yang mengajarkan perlunya keseimbangan, keselarasan serta interaksi dengan alam, lingkungan sosial dan Sang Pencipta. Tahapan prosesi adat Jawa selalu dijumpai benda-benda yang disebut uborampe atau perlengkapan dan busana yang sarat akan makna falsafah hidup (Martha, 2010:13). Oleh sebab itu peristiwa sakral itu akan dilakukan semaksimal mungkin. Setiap orang yang menyelenggarakan upacara pernikahan akan mengorbankan waktu, tenaga, pikiran, serta biaya besar untuk kelancaran terselenggaranya upacara pernikahan. Pelaksanaan pernikahan adat di masing-masing daerah mempunyai corak tata rias dan busana yang beraneka ragam, antara lain tata rias dan busana yang khas yaitu busana adat pengantin gaya Solo Basahan.

Busana pengantin adat gaya Solo Basahan merupakan busana adat di Surakarta, Jawa Tengah. Setiap tata rias dan busana menunjukan tahapan-tahapan tertentu dan menunjukan siapa pemakainya (Harmaka, 1999:50). Corak busana pengantin adat gaya Solo Basahan merupakan busana pengantin kebesaran atau busana yang tertinggi derajatnya (kebesarannya). Hal ini sangat menarik untuk dikaji karena dari perwujudannya yang berbeda dari busana pengantin lainnya. Selama ini masyarakat luas hanya mengetahui busana pengantin gaya Solo Basahan tanpa mengerti pakem dari bentuk tata rias dan busananya.

Busana Pengantin gaya Solo Basahan dikenakan dalam upacara panggih yang merupakan puncak dari rangkaian prosesi pernikahan yang dilakukan dengan mempertemukan kedua pengantin. Menurut Bratawidjaja (1985: 17) panggih merupakan prosesi pelaksanaan dipertemukannya pengantin laki-laki dan pengantin wanita setelah melaksanakan akad nikah. Pendapat lainnya menyatakan hal serupa bahwa dalam bahasa Jawa panggih artinya bertemu sehingga maksud dari upacara panggih adalah dipertemukannya kedua mempelai setelah dilakukan prosesi akad nikah. Terdapat makna dalam prosesi upacara panggih yaitu menceritakan awal pertama bertemunya kedua mempelai hingga saling jatuh cinta dan akhirnya memantabkan hati untuk memasuki bahtera perkawinan (Martha, 2010: $55)$.

Berpijak dari uraian di atas, muncul permasalahan, yaitu bagaimanakah nilai-nilai estetis yang terkandung dalam penampilan busana pengantin gaya Solo Basahan di Surakarta Hadiningrat? Oleh sebab itu, tujuan penelitian ini adalah mendeskripsikan dan menjelaskan nilai-nilai estetis yang terkandung dalam penampilan busana pengantin gaya Solo Basahan di Surakarta Hadiningrat.

\section{METODE PENELITIAN}

Penelitian ini menggunakan model analisis interaktif yaitu menganalisa data dari awal penggumpulan data sehingga dapat mempertegas bagian data yang dibutuhkan kemudian ditarik kesimpulan yang dapat dipertanggungjawabkan mengenai penampilan busana pengantin gaya Solo Basahan di Surakarta Hadiningrat.

Penelitian ini adalah penelitian kualitaif yang dilakukan melalui keterlibatan didalam lapangan atau situasi kehidupan nyata secara mendalam dan memerlukan waktu yang panjang. Keterlibatan peneliti di lapangan dalam waktu panjang tersebut bertujuan agar mengetahui dan ikut merasakan keadaan sebenarnya, sehingga data penelitian yang diperoleh peneliti sesuai yang diharapkan (Rohidi, 2011: 47).

Objektivitas penelitian kualitatif disebabkan oleh rumusan tentang situasi tertentu sebagaimana yang dihayati oleh individu atau kelompok sosial tertentu dan relevan dengan tujuan peneitian ( Karmini, 2019:9).

Sumber data dalam penelitian kualitatif yaitu berupa kata-kata dan tindakan orang yang diamati atau diwawancarai, yang dicatat melalui catatan tertulis, dan direkam melalui alat perekam berupa audio tape atau yang lainnya, selain itu dapat melalui pengambilan foto atau film. Menurut pendapat Lofland (1984) dalam Moleong (2002:157), mengemukakan bahwa sumber data utama dalam penelitian kualitatif ialah kata-kata dan tindakan, selebihnya adalah data tambahan seperti dokumen dan lain-lain. Sehingga Sumber data dalam penelitian ini narasumber (informan), Tempat dan Peristiwa, Dokumen dan Arsip. Narasumber (informan)merupakan sumber data yang sangat penting karena akan memberikan informasi-informasi yang diperlukan. Dalam penelitian kuaitatif sumber data manusia (narasumber) sangat penting perannya sebagai individu yang memiliki informasi (Sutopo, 2002:50). Informasi mengenai tempat atau lokasi yang terdiri dari tempat kegiatan dapat dimanfaatkan peneliti untuk menarik simpulan berkaitan dengan permasalahan penelitian. Narasumber (informan) yang dianggap mengetahui persoalan yang menjadi kajian penelitian ini adalah tokoh pakem tata rias dan busana adat. Tempat atau lokasi yang bekaitan dengan sasaran atau permasalahan 
penelitian juga merupakan salah satu jenis sumber data yang bisa dimanfaatkan oleh peneliti (Sutopo, 2002: 52). Sumber tambahan lain yang digunakan dalam penelitian ini berupa arsip dan dokumen-dokumen berupa rekaman tertulis, tetapi juga dapat berupa gambar atau benda peninggalan yang berkaitan dengan suatu aktivitas atau peristiwa tertentu. Dokumen dan arsip bukan hanya menjadi sumber data yang penting bagi penelitian kesejarahan, tetapi juga dalam kualitatif pada umumnya (Sutopo, 2002: 54).

Teknik pengumpulan data dilakukan dalam beberapa cara yaitu (1) Observasi, teknik observasi digunakan untuk menggali data dari sumber data yang berupa peristiwa, tempat atau lokasi dan benda serta rekaman gambar ( $\mathrm{Su}-$ topo, 2002: 64). Observasi dalam penelitian ini dilakukan di Keraton Kasunanan Surakarta Hadiningrat. Observasi dilakukan selama berkunjung dan mengamati situasi diberbagai hal. (2) Wawancara, wawancara merupakan percakapan dengan maksud tertentu. Percakapan dilakukan oleh dua pihak, yaitu pewawancara dan terwawancara yang memberikan jawaban jawaban atas pertanyaan (Moleong, 2012: 186). Wawancara dalam penelitian ini dengan narasumber KRAT.Hartoyo Budoyonagoro selaku tokoh pakem tata rias dan busana pengantin gaya Solo $\mathrm{Ba}$ sahan di Surakarta Hadiningrat. (3) Arsip dan dokumen, Menurut Sugiyono (2005: 82) Arsip dan dokumen merupakan catatan peristiwa yang sudah berlalu. Dokumen dan arsip bisa berbentuk gambar, tulisan atau karya monumental lainnya. Dokumentasi dan arsip yang digunakan dalam penelitian ini berupa informasi yang berhubungan dengan subjek dan lokasi penelitian berupa gambar dan sumber pustaka.

\section{ANALISIS DAN INTEPRETASI DATA}

Tata urutan pernikahan gaya Solo Basahan pada upacara panggih terdiri dari beberapa susunan acara. Menurut Martha (2010: 58-70) urutan panggih terdiri dari balangan gantal, ngidak tigan, sinduran, bobot timbang, tanem jero, kacar kucur, dhahar klimah, ngunjuk rujak degan, bubak kawah, tumplak punjen, tilik pitik, dan sungkeman. Terdapat pendapat yang sedikit berbeda mengenai urutan upacara panggih yaitu balangan gantal, wiji dadi, sindur binayang, timbang, tanem, tukar kalpika, kacar-kucur, dhahar kembul, mertui, dan yang terakhir sungkeman (Bratawidjaja, 2000: 44-46).

Busana yang digunakan dalam pengantin gaya Solo Basahan pada upacara panggih untuk laki-laki menggunakan bentuk Dodot Ngumbar Kunco dan untuk perempuan menggunakan bentuk dodot ageng, penampilan kedua dodot ini memakai motif alas-alasan yang serasi. Warna busana basahan yang digunakan untuk upacara panggih adalah gadhung melati (hijau-putih), untuk ijab menggunakan bango buthak (hitam-putih), dan untuk sepasaran menggunakan bangun tulak (biru-putih) (Honggopuro,
2002:155)

Saat upacara panggih, busana gaya Solo Basahan Dodot Ngumbar Kunco pada bagian belakang yang disebut kunco yang tadinya dari panti busono di pegang oleh patah laki-laki atau gandek, kemudian saat panggih dilepaskan (diumbar). Sebenarnya hal inilah yang merupakan cikal bakal dari nama busana pengantin gaya Solo Basahan bentuk Dodot Ngumbar Kunco. Pendapat tersebut serupa dengan yang dikemukakan oleh KPH. Winarno Kusumo yakni busana pengantin gaya Solo Basahan Dodot Ngumbar Kunco saat sebelum upacara panggih, kunco itu dipegang atau dibawa oleh anak kecil gandek, kemudian saat upacara panggih kunco tersebut dilepas. Peristiwa itulah yang dinamakan dengan ngumbar kunco.

Sebelum upacara panggih dimulai, pengantin wanita telah didudukkan di pelaminan, baru kemudian pengantin laki-laki datang melakukan prosesi pasrah tinampi yaitu pengantin laki-laki diserahkan kepada keluarga pengantin perempuan. Hal serupa disebutkan bahwa pengantin laki-laki telah melakukan prosesi penyerahan dirinya kepada orang tua pengantin wanita sehingga saat upacara panggih dimulai orang tua dan para pendamping pengantin putra tidak diperbolehkan ikut rombongan ke pelaminan (Bratawidjaja, 2000:46). KPH Winarno Kusumo menambahkan bahwa kunco dilepas saat panggih sehingga pengantin laki-laki sudah tidak dikanthi atau didampingi kanan dan kiri, harus dilepas jalan sendiri, kemudian kedua mempelai melanjutkan prosesi panggih sampai selesai. Berikut adalah penjelasan penampilan Dodot Ngumbar Kunco dalam rangkaian upacara panggih yang ada di Surakarta Hadiningrat:

\section{Balangan Gantal}

Sebelum kedua mempelai bertemu dalam upacara panggih, keduanya telah siap membawa gantal atau sadak. Gantal atau sadak ini berupa daun sirih yang digulung sebanyak tiga gulungan. Jarak antara kedua pengantin saat prosesi balangan gantal kira-kira dua meter dan biasanya pengantin wanita yang pertama melempar gantal-nya (Bratawidjaja, 2000:46). Jaman dahulu balangan gantal sirih dipercaya mampu membuat orang yang menyamar menjadi salah satu pengantin itu terlihat wujud aslinya (badar) (Bratawidjaja, 2000:48). Yamin (1989:6A-8A) menambahkan bahwa arah lemparan gantal dari pengantin pria ke pengantin wanita ditujukan kearah jantung dengan maksud pengantin pria mengambil jantung hati pengantin wanita sedangkan, pengantin wanita melempar ke arah lutut pengantin pria sebagai lambang akan berbakti pada suami. Pendapat lain menyatakan bahwa di keraton gantal dilemparkan oleh pengantin wanita ke arah ukup dibagian depan karena arah ini memiliki makna tertuju pada alat vital laki-laki yang merupakan lambang kesuburan ataupun cikal bakal keturunan manusia, sedangkan laki-laki melemparkan gantal diarahkan ke dada kanan wanita atau pada roncean tiba dada sebagai perlambang bahwa kasih 


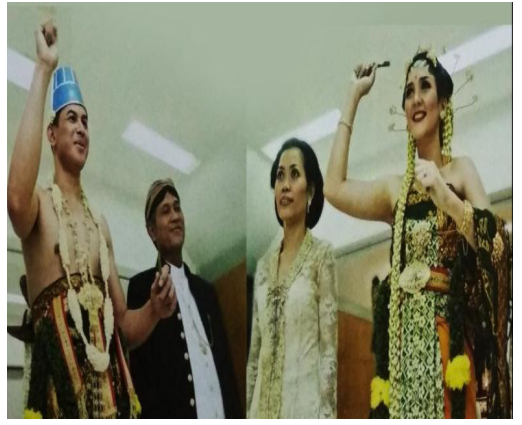

Gambar 1. Prosesi Balangan Gantal.

(Sumber: Koleksi KRAT. Hartoyo Budoyonagoro, 2017)

sayang suami terasa sampai di hati istri.

Penampilan busana pernikahan basahan Dodot Ngumbar Kunco saat dikenakan dalam prosesi balangan gantal terlihat agung dan gagah. Hal tersebut dikarenakan pengantin laki-laki mengangkat tangan dan membusungkan dada saat melempar gantal ditambah kunco yang dibiarkan menjuntai dilantai sehingga terkesan memiliki kekuasaan yang luas, gagah dan perkasa. Penampilan dodot ageng untuk pernikahan basahan wanita pada prosesi ini berpedoman pada kasusilan Jawi atau bertindak-tanduk sesuai nilai kesusilaan di Jawa misalnya, tangan tidak boleh terlalu naik sehingga memperlihatkan ketiaknya atau bergerak yang terlalu menarik perhatian.

\section{Wiji dadi}

Setelah prosesi balangan gantal selesai, kedua pengantin saling bersalaman. Saat keduanya bersalaman, sesepuh yang mengatur jalannya upacara panggih akan memberikan doa-doa sembari menyentuh kening pengantin laki-laki dengan air bunga setaman dengan harapan wong lanang kui kudu jembar wawasane artinya laki-laki harus luas wawasannya. Bunga setaman pada bokor terdiri dari bunga mawar merah, bunga mawar putih, bunga kanthil, bunga melati, dan kenanga. Selanjutnya pada tengkuk pengantin wanita juga diberi air bunga setaman dimaknai bahwa wanita harus tunduk dan menurut pada suami.

Prosesi selanjutnya wiji dadi merupakan prosesi yang dilaksanakan dengan cara pengantin laki-laki menginjak telur ayam kampung sampai pecah kemudian kakinya dicuci dengan air yang diberi bunga setaman oleh pengantin wanita. Makna yang terkandung dalam prosesi ini adalah dari namanya sendiri mengandung arti bibit yang tumbuh. Telur yang telah diinjak oleh pengantin laki-laki merupakan simbol bahwa pengantin laki-laki siap menjadi seorang ayah dan sanggup untuk memikul tanggung jawab atas anaknya. Sedangkan saat pengantin wanita membasuh kaki pengantin laki-laki dimaknai sebagai kesanggupan untuk berbakti sepenuh hati kepada suaminya (Bratawidjaja, 2000:48).

Urutan acara wiji dadi atau disebut juga ngidak tigan secara lengkap adalah selop pengantin laki-laki sebelah

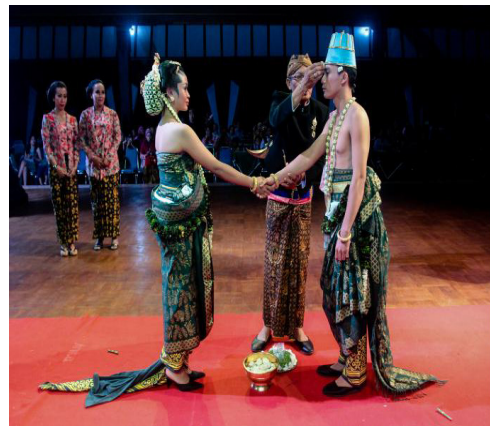

Gambar 2. Salaman dan Pemberian Doa

(Sumber: Koleksi KRAT. Hartoyo Budoyonagoro, 2017)

kanan dilepaskan, lalu diarahkan oleh pemandu pernikahan untuk menginjakkan kaki di atas telur ayam kampung sampai pecah hingga bagian kuning dan putih telur tercampur menjadi satu. Peristiwa ini melambangkan pengantin laki-laki sudah siap untuk memberikan keturunan dalam rumah tangga. Oleh sebab itulah prosesi ini disebut wiji dadi yang memiliki arti penyatuan benih yang bisa menjadi penerus keluarga (Martha, 2010: 60). Telur dipecahkan menggunakan telapak kaki kanan pengantin laki-laki bagian dalam. kemudian kaki pengantin laki-laki dibersihkan oleh pengantin wanita dengan air bunga setaman dengan cara menyiram tiga kali pada punggung kaki baru kemudian pada telapak kaki bagian dalam lalu dikeringkan menggunakan handuk. Setelah selesai pengantin wanita menghaturkan sembah bentuk bakti kepada pengantin laki-laki, kemudian untuk mengimbangi bakti tulus istrinya, suami akan mengulurkan tangan membantu istrinya berdiri.

Penampilan busana pernikahan basahan Dodot Ngumbar Kunco dalam prosesi salaman sebelum wiji dadi dimulai terlihat pengantin dengan sendirinya akan menyesuaikan gestur badan dengan busana tersebut. Misalnya pengantin akan secara otomatis membuka dada, punggung tegak, dan pandangan kedepan. Hal tersebut dipengaruhi oleh bentuk busana basahan yang tidak bisa membuat punggung membungkuk, akan otomatis lebih nyaman untuk tegak karena terdapat lipatan-lipatan dodot yang menyangga bagian perut. Sanggul juga membuat wajah pengantin secara otomatis lurus menghadap depan, tidak terlalu keatas atau miring kanan kiri karena dalam pemasangan sanggul sudah dipastikan seimbang. Saat prosesi wiji dadi kesan gagah dan disegani bertambah karena dalam prosesi ini pengantin laki-laki diperlakukan sangat istimewa seperti raja ketika di basuh kakinya oleh pengantin wanita. Prosesi wiji dadi ini membuat celana cinde menjadi salah satu pusat perhatian. KPH. Winarno Kusumo berpendapat bahwa berdasarkan pedoman dari kasusilan Jawi celana cinde harus tetap menutup mata kaki. Sedangkan penampilan dodot ageng untuk pernikahan basahan wanita saat berjongkok terlihat tetap anggun karena terdapat kain samparan dan songgo bocong yang menjadi perhatian. Walaupun sedikit susah dalam bergerak namun sesepuh atau pemandu prosesi akan membantu pengantin wanita. 


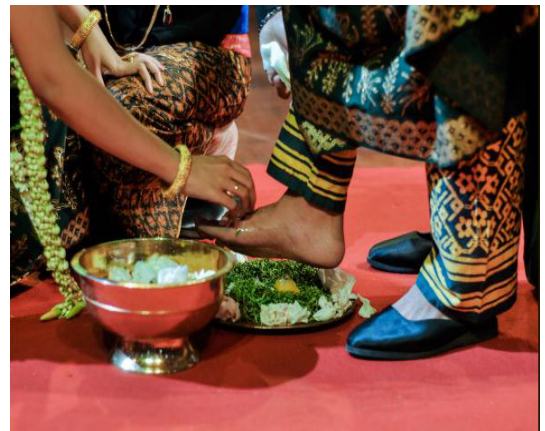

Gambar 3. Prosesi Wiji Dadi

(Sumber: Koleksi KRAT. Hartoyo Budoyonagoro, 2017)

\section{Sindur Binayang}

Sindur binayang atau sindur binayung adalah prosesi menyelimuti pundak kedua mempelai dengan kain sindur berwarna merah dan pinggirnya berwarna putih. Setelah prosesi wiji dadi kedua mempelai berjalan saling berdampingan menuju ke pelaminan diiringi ibu yang ada dibelakang kedua pengantin sambil menyelimuti dengan kain sindur dengan harapan keduanya bisa menyatukan dan mendapatkan keturunan. Ayah pengantin putri berada di depan pengantin yang dimaknai sebagai pembuka jalan bagi kedua mempelai untuk masuk kelembaran hidup yang baru. Jari kelingking kedua mempelai saling mengait dan menyetuh pangkal dari pusaka yang berada di belakang ayah (Martha, 2010:62).

Pendapat serupa mengenai prosesi ini dilakukan dengan cara kedua mempelai di giring menuju pelaminan oleh ayahnya dan ibunya menutup bahu kedua pengantin dengan kain sindur. Makna dari prosesi ini ialah seorang ayah menunjukkan jalan yang benar untuk kedua pengantin agar keduanya menemui kebahagiaan berumah tangga. ibu berada dibelakang sebagai penyemangat (tut wuri handayani) (Bratawidjaja, 2000:48).

Sekarang ini terdapat perkembangan dari prosesi sindur binayang yang telah di perbolehkan oleh pihak Keraton Kasunanan Surakarta. Prosesi sindur binayang dilakukan dengan cata tangan pengantin wanita menggandeng lengan pengantin laki-laki. Ibu berada di belakang kedua pengantin dengan menyelimuti bahu kedua pengantin dengan kain sindur. Dahulu ayah berada di depan namun sekarang di posisikan di samping ibu untuk menemani ibu. Selain itu untuk lebih memperlihatkan penampilan dari busana pernikahan basahan yang agung. Saat pengantin berjalan, tangannya pengantin wanita akan konsisten sedikit membuka sedikit keatas karena terganjal bocong dan buntal sehingga menampakkan keanggunan.

\section{Bobot Timbang}

Prosesi ini dilaksanakan dengan cara ayah pengantin wanita memangku kedua memepelai, kemudian sang ibu pengantin putri menanyakan berat mana antara keduannya, lalu oleh sang Ayah dijawab sama beratnya karena keduannya sama-sama anak (Yamin, 1989:6A-8A). Makna dari

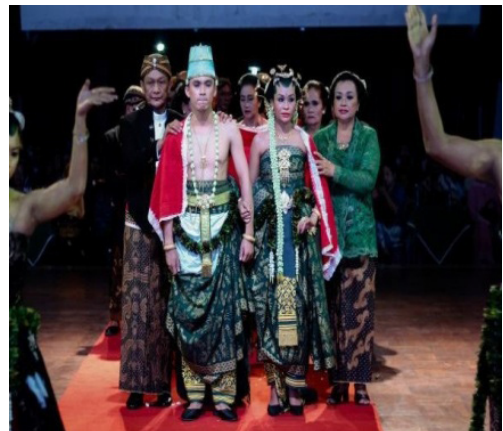

Gambar 4. Prosesi Sindur Binayang

(Sumber: Koleksi KRAT. Hartoyo Budoyonagoro, 2017)

prosesi ini adalah ayah pengantin wanita menyatakan kasih sayangnya dengan menganggap anak menantu sama seperti anak kandungnya sendiri (Bratawidjaja, 2000:49).

Prosesi ini dalam buku tata urutan pernikahan karangan Martha maupun Bratawidjaja diikut sertakan dalam prosesi upacara panggih namun, dalam aturan di Keraton Kasunanan Surakarta prosesi bobot timbang tidak ditampilkan dalam upacara panggih. Prosesi ini ada di upacara lamaran, karena saat panggih mereka sudah resmi menjadi suami istri jadi tidak perlu ditimbang lagi kasih sayangnya.

\section{Tanem}

Prosesi tanem adalah ketika ayah pengantin wanita mendudukkan kedua memepelai di pelaminan. Pendapat ini sejalan dengan pernyataan yang menerangkan bahwa tanem adalah saat kedua pengantin didudukkan di pelaminan oleh ayah pengantin wanita. Prosesi tanem adalah ketika kedua pengantin didudukkan di pelaminan oleh ayah pengantin wanita. Prosesi ini memberikan kesan direstuinya kedua mempelai menjadi sepasang suami istri (Bratawidjaja, 2000:49). Saat mendudukkan kedua pengantin, ayah diberi ucapan selamat dan doa agar kedua pengantin hidup rukun dan kedua orang tua akan selalu membimbing keduanya atau tidak melepaskan begitu saja anaknya dalam mengarungi bahtera rumah tangga (Martha, 2010:63).

Penampilan busana pernikahan basahan Dodot Ngumbar Kunco dalam prosesi ini terlihat tidak begitu jelas karena tertutupi oleh ayah pengantin wanita. Saat duduk kedua pengantin akan secara naluriah menyesuaikan diri mencari posisi yang nyaman. Berdasarkan kasusilan Jawi kedua pengantin akan duduk dengan sangat berhati-hati, tidak menimbulkan gerakan yang terlalu berlebihan dan cenderung menunduk yang terkesan seperti wujud kepatuhan kepada ayah.

\section{Kacar-kucur}

Prosesi ini dilaksanakan dengan cara pengantin laki-laki menuangkan beras beserta kacang-kancangan ke pangkuan pengantin wanita, hal ini memiliki makna bahwa pengantin laki-laki sudah siap menjadi suami yang akan memberikan upah hasil jerih payahnya kepada sang istri untuk dikelola dengan baik (Bratawidjaja, 2000:49). 


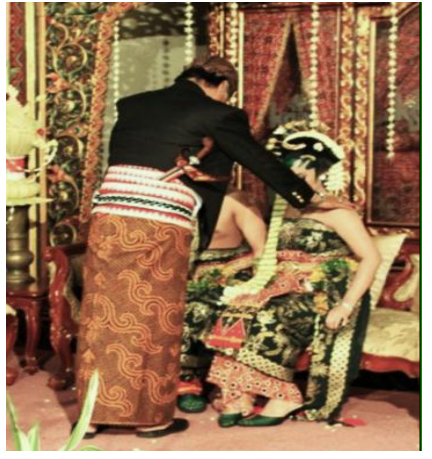

Gambar 5. Prosesi Tanem

(Sumber : Dokumentasi Pribadi Meikowati, 2017)

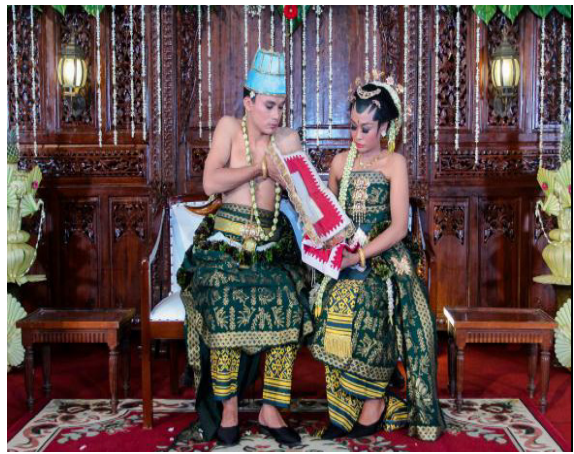

Gambar 6. Prosesi Kacar Kucur

(Sumber: Koleksi KRAT. Hartoyo Budoyonagoro, 2017)
Setelah selesai kucuran tersebut dibungkus dengan erat lalu dititipkan kepada ibu pengantin wanita sebagai bukti kesungguhan pengantin laki-laki nantinya akan menafkahi keluarganya dengan baik. Pendapat yang lain menyatakan bahwa makna dari kucuran yang di berikan kepada ibu adalah sebagai harapan doa kepada ibu agar keluarga yang dibangun nantinya dilimpahkan rezeki baik material maupun rezeki didekatkan dengan orang-orang baik.

Perlengkapan upacara kacar-kucur ini terdiri dari tikar pandan, beras kuning, uang logam receh dari nilai paling rendah sampai paling tinggi, biji-bijian, kacang-kacangan, bumbu dapur, kembang telon yaitu mawar, melati, kenanga, terakhir adalah kain sindur untuk wadahnya (Martha, 2010:64). Sedangkan sesuai dengan adat upacara kacar kucur hanya berisi kacang-kacangan, kedelai, empon-empon, dan uang logam.

Penampilan busana pernikahan basahan Dodot Ngumbar Kunco dalam prosesi kacar kucur dari depan terlihat detail motif dari dodot alas-alasan dan celana cinde. Hal tersebut dikarenakan posisi kaki pengantin laki-laki yang membuka sehingga kain dodot terbentangkan. Penampilan dodot ageng untuk pernikahan basahan wanita terkesan anggun karena kedua kaki menutup dan bagian kampuhnya menjuntai disamping kiri. Gabungan dari busana keduanya menampilkan keserasian yang diberi warna kontras sebagai titik fokus prosesi yaitu pada kain sindur berwarna merah sebagai wadah kacar kucur. Penampilan selanjutnya dapat diamati saat kedua pengantin menyerahkan bungkusan kucuran kepada ibu pengantin wanita. Terlihat oleh para tamu busana Dodot Ngumbar Kunco bagian belakang berupa kunco yang terkesan gagah menjuntai sampai ke lantai diimbangi oleh penampilan busana dodot ageng yang terkesan sangat rapi dan ditambah keanggunan dari songgo bocong-nya.

\section{Dhahar Kembul}

Dhahar kembul merupakan prosesi saling suap menyuapi dengan makanan dan minuman yang sudah tersedia. Prosesi ini adalah simbol dari hasil rezeki yang didapatkan nantinya akan digunakan bersama untuk kepentingan keluarga (Bratawidjaja, 2000:49). Selain itu dahar kembul sebagai gambaran kemesraan antara suami dan istri. Dahulu, prosesi ini tidak dilakukan didepan para tamu tapi dilakukan saat kedua mempelai ada di kamar pengantin dan disaksikan oleh kerabat dekat saja (Martha, 2010:66). Dhahar kembul dimulai dengan menyendok nasi putih kemudian di tutulkan pada lauk pauk, baru yang kedua nasi putih dan lauk pauk yang dipilih bebas oleh pengantin. Hal tersebut dimaknai nasi putih adalah simbol lembaran baru yang akan ditempuh kedua mempelai, putih merupakan gambaran tidak boleh ada dusta sehingga diharapkan keduanya bersih dan saling jujur satu sama lain kemudian akan mereka isi sesuai dengan tujuan keduanya dalam berumah tangga. Setelah selesai makan merekan akan saling memberikan satu sama lain minum air putih.

Penampilan busana pernikahan basahan Dodot Ngumbar Kunco dalam prosesi dhahar kembul terlihat keduannya sangat serasi dan anggun. Posisi duduk berhadap-hadapan tidak membuat keduannya merasa kesulitan bahkan, dengan mengenakan busana Dodot Ngumbar Kunco dan dodot ageng putri ini secara otomatis membuat badan tegak lurus, tidak nampak bungkuk sehingga menambah kegagahan pengantin laki-laki dan menambah keanggunan pengantin wanita. Prosesi menciptakan suasana keharmoisan dan kemesraan diantara kedua mempelai sehingga diperlukan busana yang nyaman untuk mendapatkan dikenakan dalam suasana tersebut. Terbukti busana basahan Dodot Ngumbar Kunco mampu menginterpretasikan busana yang agung namun tetap nyaman saat dikenakan.

\section{Mertui}

Kedua orang tua pengantin putra datang untuk menengok upacara perkawinan anaknya dijemput oleh besannya (Bratawidjaja, 2000: 49). Hal ini dilakukan karena saat sebelum upacara panggih, kedua orang tua pengantin laki-laki telah menyerahkan anaknya kepada orang tua pengantin wanita sehingga orang tua pengantin laki-laki datang saat upacara panggih akan selesai.

Terdapat perkembangan dari upacara panggih yang telah disetujui oleh pihak Keraton Kasunanan Surakarta bahwa prosesi mertui langsung dilakukan setelah upacara tanem, 


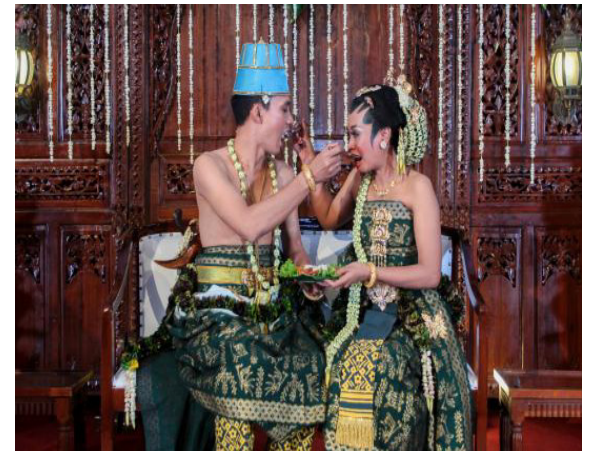

Gambar 7. Prosesi Dhahar Kembul

(Sumber: Koleksi KRAT. Hartoyo Budoyonagoro, 2017)

disebabkan terdapat banyak penyesuaian karena orang tua laki-laki memiliki hak yang sama dengan orang tua pengantin wanita untuk ikut menyaksikan upacara panggih anaknya dan mendoakan kedua mempelai maka orang tua pengantin ikut duduk disamping kiri pengantin setelah prosesi tanem jero.

Penampilan busana pernikahan basahan Dodot Ngumbar Kunco dalam prosesi mertui nampak sangat gagah seperti raja sehari. Dodot ageng yang dikenakan oleh pengantin wanita juga menampilkan seperti ratu yang anggun. Senyum dan gestur badan kedua mempelai terlihat indah ditujukan kearah depan agar semua tamu dapat menyaksikan kebahagiaan dan keagungan busana yang dikenakan memang seperti ratu dan raja sehari.

\section{Sungkem}

Sungkem atau ngabekten ialah prosesi ketika kedua mempelai berlutut untuk dihadapan kedua orang tua dan mertua sebagai tanda bahwa keduannya akan selalu berbakti dan menghormati orang tuanya. Pada saat sungkeman kedua mempelai akan memohon doa restu dan mengucapkan terimakasih kepada kedua orang tua serta mertua mereka (Bartawidjaja, 2000: 50).

Tatanan prosesi sungkeman yang pertama adalah mengambil keris pengantin laki-laki. Saat sungkem tidak diperbolehkan membawa senjata apapun. Sungkeman dilakukan pertama dari pihak pengantin wanita sungkem kepada ibunya kemudian pengantin laki-laki kepada ayah mertua lalu bergantian, saat sungkem kepada orang tua pengantin laki-laki, pengantin laki-laki pertama sungkem kepada ibunya dan pengantin perempuan sungkem kepada ayah mertua lalu bergantian. Hal ini merupakan simbol bahwa ibu sebagai wanita yang memiliki beban paling berat ketika hamil, melahirkan, dan mengurus keluarga harus menjadi orang pertama yang dimintai restu dan doanya.

Penampilan busana pernikahan basahan Dodot Ngumbar Kunco dalam prosesi sungkem memperlihatkan busana bagian belakang. Kunco yang terjuntai dilantai terkesan membuat busana ini nampak megah. Terlihat dua ukup yang memepermanis tampilan kain dodot alas-alasan.

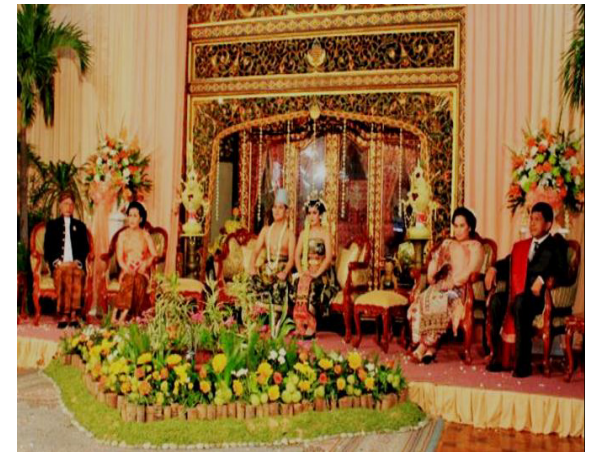

Gambar 8.Prosesi Mertui

(Sumber: Koleksi KRAT. Hartoyo Budoyonagoro, 2012)

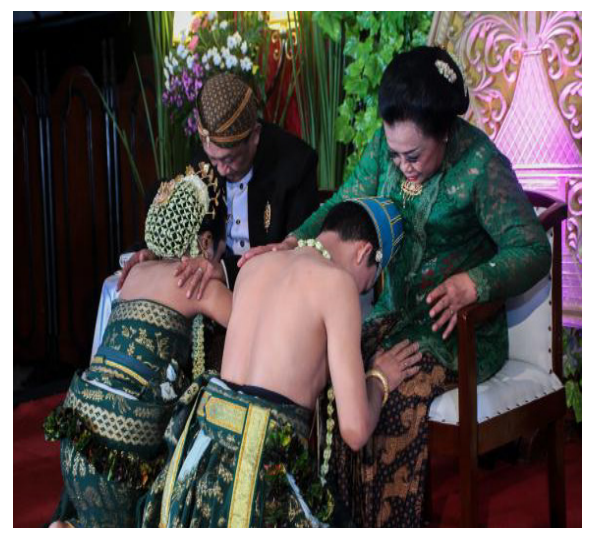

Gambar 9. Prosesi Sungkem

(Sumber: Koleksi KRAT. Hartoyo Budoyonagoro, 2017)

Busana pernikahan basahan dodot ageng yang dikenakan pengantin wanita menampakkan bagian dodot ageng yaitu songgo bocong yang dipermanis dengan hiasan buntal. Sehingga pantat mempelai wanita tidak begitu tegas terlihat atau tersamarkan sehingga nampak sopan dipandang para tamu undangan.

\section{SIMPULAN}

Berdasarkan hasil penelitian, dapat disimpulkan bahwa nilai-nilai yang terkandung dalam penampilan busana pengantin Gaya Solo Basahan di Surakarta Hadiningrat berupa wujud pertunjukkan seni oleh pengantin yang menjadi raja dan ratu sehari yang di dalamnya terdapat nilai-nilai meliputi kasih sayang, rasa bakti, tanggung jawab, kesetiaan, kebahagiaan, keserasian, semangat, kemesraan, kejujuran, keharmonisan, dan kesopanan.

Nilai-nilai tersebut menjadi representasi nilai estetis busana Solo Basahan sebagai bentuk pertunjukkan seni yang terdapat dalam upacara panggih yang meliputi Balangan Gantal, Wiji Dadi, Sindur Binayang, Bobot Timbang, Tanem, Kacar-kucur, Dhahar Kembul, Mertui, dan Sungkem.

\section{DAFTAR RUJUKAN}

Bratawidjaja, Thomas Wiyasa. 1985. Upacara Perkawinan Adat Jawa. Jakarta: Pustaka Sinar Harapan. 
Djelantik, A.A.M. 1999. Estetika Sebuah Pengantar. Bandung: Masyarakat Seni Pertunjukan Indonesia.

Honggodipuro, Kalinggo. 2002. Batik sebagai Busana dalam Tatanan dan Tuntunan. Surakarta: Yayasan Peduli Keraton Surakarta Hadiningrat.

Karmini, N. N. (2019). Nilai-Nilai Budaya Dalam Tam Tam. Mudra Jurnal Seni Budaya, 34(1), 8-18. https://doi. org/10.31091/mudra.v34i1.630

Martha, Puspita. 2010. Pengantin Solo Putri dan Basahan. Jakarta: PT. Gramedia Pustaka Utama.

Moleong, Lexy J. (2007). Metodologi Penelitian Kualitatif. Bandung: PT.Remaja Rosdakarya Offset.

Sugiyono. 2011. Metode Penelitian Kuantitatif Kualitatif dan $R \& D$. Bandung: CV Alfabeta.

Sutopo, H.B. 2002. Metodologi Penelitian Kualitatif. Surakarta: UNS Press.

Rohidi, T. R.2011. Metodologi Penelitian Seni. Semarang: Cipta Prima Nusantara 